\title{
Evolution of the Modern Voter: A Branding Perspective
}

\section{Dr. Amit Kumara}

${ }^{a}$ Assistant Professor, Institute of Business Management, GLA University, Mathura, Uttar Pradesh. E-mail: amit.kumar@gla.ac.in

Article History: Received: 11 January 2021; Accepted: 27 February 2021; Published online: 5 April 2021

\begin{abstract}
The concept of branding is to be found in every aspect of our lives and on a day-to-day basis. It has made its presence felt in almost every domain of human existence to such an extent that a sense of surety and assuredness seeps in whenever we buy a branded product over an unbranded one based on our positive experience related to its usage. The concept of branding could be applied to the field of politics as well in the modern times based on the evolution of politics. Political branding has found its place in the modern scheme of things when one talks about the contemporary facet of polity. Such a phenomenon is quite popular in the western democracies and has been a late entrant in the Indian scenario but the effectiveness of the same is second to none. This research paper would delve into the rise of political branding pertaining to India thereby exploring its effectiveness in turning the tide as far as existing patterns of voting are concerned which were very much visible in the last general election of the nation. The work would also focus upon the performance of the regional political brands and how the electorate of India has came to vote differently in the two sets of election, national and state.
\end{abstract}

Keywords: Political Branding, Political Participation, General Election, State Election.

\section{Introduction}

Branding as a concept is to be found in every aspect of the society (Adamson, 2006). There is not a single aspect of our lives which is untouched by it. The assuredness, relatability, believability, connect with branding brings with it differentiates a branded product from an unbranded one.

As per Williams (2000), Clifton et al., (2009) any amalgamation of slogans, names, symbols, colours, shapes, signatures, letters, packaging, product design, advertising, logos which feature together and marketing them altogether gives an immensely identifiable outline to a distinct goods or service which is immediately decipherable from others.

The above characterization goes a long way as far as deciding how one should go about describing a brand along with the understanding of what essentially makes a brand. Organizations have found it quite pertinent to differentiate their products from others on the virtue of branding (Smith and French, 2011). Branding gives that distinctiveness to a product which differentiates it from its rivals on the virtue of it being perceived as a superlative version of the rival product (Clarke, 2004). Such is the might of branding that it raises the bar for the competition eventually knocking the socks of it.

The past decades have seen the rise in application of the various aspects of branding in the field of politics (Singer, 2002). This is particularly true in the context of western democracies (Enemaku, 2003). Brand Obama did wonders for his party the Democrats in the US, so did brand Blair for the Labour Party in the UK and brand Trudeau for the Liberal Party in Canada bringing their respective parties to the fore amidst a strong contender. This can be done on the virtue of running a formidable campaign quite essential from the perspective of political marketing (Stromback, 2007). Scammell (1999) opines that politics and marketing could be interwoven together bringing out the potential of each other.

Prior to the general election of 2014, the Indian political system didn't bear much similarity to the brandcentric nature of politics as had become the norm in western democracies. However, the same has seen a tectonic shift in the last few years. The rise and rise of brand Modi, first in 2014 and then again in 2019 has left psephologists looking for answers about the pull which he generates among the masses whether at the national level or regional level (though there have been some exceptions to it in the past as well as present such as Mamata Banerjee in West Bengal, Late J Jayalalitha in Tamil Nadu, Naveen Patnaik in Odisha, KCR in Telangana, YSJ Reddy in Andhra Pradesh), and made an overwhelming presence felt across the board.

This research paper would explore the impact of brand Modi on overall participation in the last general election and give a commentary on the influence which it garnered on the minorities segment of the society, 
which was traditionally not seen as the bastion of support for BJP, the political outfit which brand Modi represented in the general election.

\section{Voting Patterns, Vote \& Seat Share in the Seventeenth Lok Sabha Election}

The last general election was the largest exercise of voting franchise on the globe related to a democratic political system (wikipedia.org/wiki/2019_Indian_general_election). It was conducted in a total of seven phases and span across April 11 to May 19, 2019 for the formation of the seventeenth Lok Sabha. 67.1\% of the eligible voters, the highest percentage ever, voted during the election out of 900 million eligible electorate, another alltime record. Almost 603 million voters exercised their right to vote their preferred leader and party to power.

Though this number is less than the half-mark of the total population of the nation which stood at close to 1.3 billion, still it was a monumental achievement for the success of political system in our nation as it exhibited the trust level shown by the electorate in the democratic set-up of the country.

Coming to the vote share garnered by the major political parties and alliances during the 2019 general election, Bharatiya Janata Party (BJP) alone won 303 seats, 21 more than it did in 2014 (282) and cornered a vote share of $38 \%$ an upswing of $7 \%$ as compared to the last time. This was yet another vindication to the image of brand Modi in the eyes of his supporters as well as detractors as those questioning the relevance of a party winning only $31 \%$ vote share in 2014 general assembly and still calling the shots. It was for the first time in the annals of political elections in India for the Lok Sabha that an incumbent government was able to storm back to power with an improved mandate that too with a higher vote share.

This feat becomes all the more prominent keeping in mind that the party in question is not the Indian National Congress (INC), the Grand Old Party of the country. One may point out the general election of 1984 when Congress came back in power with a stunning performance winning 404 and BJP being relegated to a mere 2, that election was fought in the aftermath of assassination of Late Indira Gandhi and the sympathy wave for Congress triumphed every other issue including the Emergency imposed during her tenure.

Its chief rival party Indian National Congress also fared better than its performance of last time but still remained in doldrums. It got 52 seats, 8 more than the historic low of 44 which came along its way in 2014 . However, this uptick was not reflected in the vote share which went down by $1 \%$ to $19 \%$.

(wikipedia.org/wiki/Results_of_the_2019_Indian_general_election) Overall, the BJP-led NDA won 353 seats and INC-led UPA won 91 seats. Other parties and their alliances were able to win 98 seats. The NDA was able to garner $45 \%$ vote share which was a clear indicator of the preference of the masses who voted in favour of the alliance. This was a marked improvement over the 38\% vote share which the alliance got in 2014 general election.

Coming to the share of seats as won by the various parties during the seventeenth Lok Sabha election, BJP came on the top and won 56\% of the total seats (303 of 543 seats), INC won 9.6\% (52 seats), DMK won $4.4 \%$ (24 seats), TMC and YSR-Congress won 4\% (22 seats each), Shiv Sena won 3.3\% (18 seats), JDU won 3\% (16 seats), BJD won $2.2 \%$ (12 seats) and BSP won 1.8\% (10 seats), TRS 1.7\% (9 seats) and others $10.2 \%$ (55 seats).

\section{Regional Political Brands in India \& Brand Modi}

What was remarkable about this mandate was the appeal of brand Modi which transcended across religions, castes, affluence and education levels of the voters. The charisma of Narendra Modi was felt across all the income groups. Not only this, the backward classes, namely, the Scheduled Castes and Scheduled Tribes preferred brand Modi over any other brand, a mammoth achievement for the party which was traditionally not seen in this context.

The pertinent observation which could be made from the above data related to the seat share is the fact that during the general election of 2014, the AIADMK, a regional party of Tamil Nadu, was having the third-largest seat share with 37 seats, just seven less than the national party INC (which had 44 seats) riding on the charisma of its leader Late J Jayalalitha whereas the rival DMK remained seat-less. The fortunes reversed in the 2019 general election with DMK emerging as the third-largest party in the country in terms of seat share winning 24 seats whereas AIADMK had to be content with just a single seat. Such could be the difference of a political brand, in this case it was pull of the regional political brand "Amma". The pull of TMC in West Bengal went down a bit as it could win only 22 seats as compared to the 2014 general election where it won 34 seats though it 
still continued to be the fourth-largest party in the country in terms of seat share thus showcasing the relevance of its regional political brand Mamata Banerjee intact to a large extent. YSR-Congress, another regional biggie from Andhra Pradesh, came up triumph with 22 seats emerging as the joint fourth-largest party in the country in terms of seat share thanks to the pull of its regional political brand Jaganmohan Reddy. The party won 13 more seats than it did in 2014 general election. Shiv Sena, an NDA ally at the time of election, won the same number of seats as it did during 2014 and had the same seat share in the seventeenth Lok Sabha. The table turned on its head for JDU, a regional party from Bihar, which allied with NDA and benefitted from the same. From a meager 2 seats in 2014 general election, it was catapulted to the big league with 16 wins in terms of seat share. This went on to show the reinforcement effect which could result from the alignment of a regional political brand like Nitish Kumar, the CM of Bihar, with a national political brand like brand Modi and the gains arising out of it. Another regional political brand which suffered due to Modi juggernaut was Navin Patnaik whose charisma took a hit in Odisha whose party BJD lost 8 seats in the Lok Sabha election as compared to their tally in 2014 of 20 seats. At the same time, his party won the majority for the state assembly election which was held simultaneously with the general election thus getting mixed response from the same electorate. Another regional party which gained from its calculated move against brand Modi was BSP in the state of Uttar Pradesh were it won 10 seats in 2019 whereas it failed to win even a single seat in 2014 general election despite being the party with the thirdlargest vote share (4.2\%) in that election. It had much to do with the pull of its regional political brand Mayawati also known as "Behenji". KCR-led TRS in Telangana was one of the few regional parties which performed like it did in the last general election by winning 9 seats in the general election, 2 less than in 2014 which was commendable keeping in mind the fact that he decided not to align with any of the two alliances of NDA or UPA like his neighbor Jaganmohan Reddy from Andhra Pradesh and has been able to woo the voters during both the general and state elections.

For a brand to be a top-performer and triumph over its competitors, it needs to be trustworthy, believable, consistent and performing. Brand Modi fulfils all these parameters and much more. He is the glue which binds the NDA together spearheading its campaign alone on his shoulders be it the general election, state assembly election, he campaigns uninterruptedly for the alliance and specifically for his party. Brand Modi has made the electorate believe in the NDA story for a better India seeking a re-election for his leadership which was given with an overwhelming majority by the voters thus going on to prove that he is the true political brand in every sense keeping into perspective the diverse and complex nature of Indian politics which makes it extremely difficult for any political party to appeal to the disparate set of electorate from different walks of life. But brand Modi was able to do so and repeat its success of 2014 in 2019 and even go better with it as was evident from the improved tally of 303 for BJP from 282 of 2014 . The counter-narrative built by his opponents fell flat and was summarily rejected by the voters thus depicting the strong pull he has and trust reposed on his brand of politics by the masses.

Further, there were two interesting instances from two different parts of the country during the last general election which highlighted the significance of aligning or reverse-aligning with brand Modi. Brand Nitish Kumar, a regional political brand from Bihar gained immensely after coming under the fold of brand Modi in his home state with his party JDU winning 16 seats in 2019 whereas he won a mere 2 seats in the 2014 general election. On the other hand, there was N Chandrababu Naidu who ditched the NDA in 2019 because of which brand Naidu became non-aligned with brand Modi thus suffering huge loss both in the Lok Sabha 2019 election where his party TDP got just 3 seats as compared to 15 seats won by BJP-TDP combine in 2014 general election as well as the state assembly election where his party was outsmarted by Jaganmohan Reddy. This goes on to prove the efficacy of aligning with the one true national political brand which has the ability and appeal to make or mar the prospects of regional political brands in their own states.

\section{Regional Party Performances and Other Trends during the 2019 General Election}

What are interesting are the changes in fortunes of those regional parties which saw their performance change dramatically due to one factor or the other. Such strong regional brands like Mamata Banerjee of Trinamool Congress suffered a jolt in West Bengal and saw the tally of her party go down from an all-time high of 34 in the 2014 general election to 22 in the 2019 event with BJP gaining seats at the expense of Trinamool Congress. Similar was the story of Naveen Patnaik who, though won the state assembly election and became the CM of Odisha for a record consecutive fifth term, saw the tally of his party go down to 12 in the 2019 general election from 20 in 2014 with the BJP making inroads in the state.

This throws an interesting analogy wherein the electorates votes in an entirely different manner when voting for the general election as compared to the state election as they presume that the local leaders and regional parties would serve their purpose better as compared to national parties and even iconic political brands like 
brand Modi are not enough to convince them to vote for a national party like BJP when choosing their representatives for the state assembly. Then there is the case of Nitish Kumar led Janata Dal United which won just 2 seats in 2014 general election when it fought against BJP whereas it won 16 seats in the 2019 exercise as a part of the National Democratic Alliance, the alliance of which BJP is the main party. At the same time, the JDU formed a Grand Alliance with Congress and RJD in the run-up to the state assembly election in 2015 and won.

The regional permutation and combination got to yet another level in the most-crucial state of Uttar Pradesh which sends 80 MPs to the lower house of the Parliament. The two regional rival parties, namely, Samajwadi Party and Bahujan Samaj Party formed a grand alliance, Mahagathbandhan, with Indian National Congress being the third ally (much on the lines of the Mega Alliance which was formed by the two rival regional parties JDU and RJD in Bihar with Congress being the third partner during the 2015 state assembly where they were able to buck the Modi wave and form a government in the state) for fighting the Lok Sabha election against the BJP-led NDA in the state. The biggest beneficiary of this alliance was BSP which won 10 seats whereas it failed to win any seats in 2014. Samajwadi Party fared exactly as it did in 2014 winning 5 seats. Congress won the solitary seat from Rae Bareli. Rahul Gandhi, the President of the party failed to retain his seat from Amethi which came as a huge morale booster for BJP. Overall, BJP won a remarkable 62 seats and its ally Apna Dal (Sonelal) winning another 2 seats. This result becomes significant in the view of the strong fight put up by all the rival parties who came together, despite differing ideologies, with the sole motive of defeating BJP-led NDA in the state but fell short of doing so.

(indiatoday.in/elections/lok-sabha-2019/story/election-results-2019-bjp-nda-performance-south-india-keralakarnataka-tamil-nadu-andhra-pradesh-telangana) The absence of the charismatic persona of Late J Jayalalitha in the 2019 general election was sorely felt by the AIADMK in Tamil Nadu where it went spiraling down from an all-time high of 37 seats during the 2014 general election which it fought on the name of "Amma" to again an all-time low of just one seat despite being in alliance with BJP. On the other hand, the other main party of Tamil Nadu, DMK made the maximum gains by winning an impressive 24 seats in 2019 while it was seat-less in 2014 due to the onslaught of brand Amma.

Another curious case is that of N Chandrababu Naidu-led TDP in Andhra Pradesh who fought and won handsomely the 2014 general election as an NDA partner with the alliance garnering 15 seats along with TDP forming the government in the state. Cut to 2019, he suffered a jolt at the hands of Jaganmohan Reddy-led YSRCongress which won 22 seats out of 25 as well as mandate for ruling the state in the simultaneously held state assembly election. The TDP won only 3 seats in the general election of 2019 and lost power in the state assembly election too.

Yet another interesting observation is related to the performance of the left parties during the 2019 general election in yet another south Indian state Kerala where despite being in the power, the left parties won just 2 of the 20 seats with Congress being the main beneficiary winning 15 of those seats whereas it won 8 seats in 2014 . What makes this even more interesting is the aspect that in terms of vote share, the left parties gained but in terms of seats won they went down.

Of the southern states, the newest of them, Telangana, was the most consistent in terms of the 2019 performance matching with that of the 2014 general election one. The KCR-led TRS won 9 out of the 17 seats, a loss of only 2 seats over previous election. Here it would be pertinent to observe that KCR was prudent enough to advance the state assembly election by six months and won handsomely in the December 2018 state assembly election as he took the two elections one at a time within a span of six months. Such was not the virtue of $\mathrm{N}$ Chandrababu Naidu who spent these crucial months lobbying against the NDA which proved nothing but disastrous for him as his party lost its credibility in both the state and general elections when they happened simultaneously in 2019.

The above discussion on regional parties was restricted to mainly those which fought the present or previous Lok Sabha elections as an opponent of BJP-led NDA. There were the NDA allies like Shiromani Akali Dal in Punjab which suffered a loss of 2 seats in the 2019 general election as compared to their performance in the 2014 general election when it won 4 seats. (wikipedia.org/wiki/2017_Punjab_Legislative_Assembly_election) Here it would be pertinent to highlight that riding on the charisma of its regional political brand Capt. Amarinder Singh who single-handedly carried out the INC to majority in the state assembly polls held in 2017. His charisma ensured that INC did well during Lok Sabha election as well winning 8 seats, as compared to a mere 3 seats in the 2014 general election. 
The BJP performed below par in south India and won handsomely only in the state of Karnataka, winning 25 of the 28 seats, remaining winless in the crucial states of Tamil Nadu, Andhra Pradesh and Kerala. The party got a total of 30 out of the combined 130 seats up for grabs in the four states of south India. The pull of brand Modi was unable to yield desired effects in the south India except in Karnataka. Still it was enough for the party, and the alliance, to finish on top with 353 seats for the NDA and 303 for BJP in a fast-past-the-post system where halfway mark is 272 in the lower house of the Parliament with the total seats being 543.

\section{Conclusion}

To conclude, the author would like to comment on the rise of political branding in the Indian scenario in the form of a formidable political brand, brand Modi. It established itself as a pro-development brand and successfully convinced all the segments of the society, irrespective of their past affiliation and apprehensions, to vote for it first in 2014 and then again in 2019 with even better performance. This research paper highlighted the voting pattern as emerged during the 2019 general election and the related trends which came to the fore in the aftermath of the election. The paper also dwelled upon the performance of various regional political brands and compared their efficacy in relation to the general election of 2014 and how they stacked up against brand Modi which moved from strength to strength in the past five years thus easily bucking the anti-incumbency trend and providing a single-party non-congress majority government for a second straight term in the process bringing down the bargaining power of the alliance partners which used to be the trademark of Indian politics at the central level in the pre-Modi era. The paper also talked about alignment or reverse-alignment with brand Modi changed the fortunes of regional political brands in some states. Then there are other regional political brands which remained neutral and did better by not siding with any of the two alliances. The paper highlighted the might of brand Modi and how it brought majority of the electorate together in a diverse and complex democracy like India which speaks volumes about the pull of this national political brand.

\section{References}

1. Adamson, A.P. (2006). Brand Simple: How the best brands keep it simple and succeed. New York: Palgrave Macmillan.

2. Clark, K.A. (2004). Brandscendence: Three essential elements of enduring brands. Dearborn Trade Publishing.

3. Clifton, R., Ahmed, S., Allen, T., Anholt, S., Barwise, P., \& Blacket, T. (2009). Brands and Branding (The Economist Series). The Economist, Bloomberg Press, New York, NY, USA.

4. Enemaku, O.S. (2003). The Role of Political Parties in A Democracy: A Communication Perspective. In UNILAG Communication Review.

5. Scammell, M. (1999). Political Marketing: Lessons for Political Science. Political Studies, 47(4), 71839.

6. Singer, C. (2002). Bringing brand savvy to politics. Brandweek, 43(34), 19.

7. Smith, G., \& French, A. (2011). The political brand: A consumer perspective. In P.R. Baines (Ed.), Political Marketing, London: SAGE, 1-3, 1-18).

8. Stromback, J. (2007). Political Marketing and Professionalized Campaigning. Journal of Political Marketing, 6(2/3): 49-68.

9. Williams, G. (2000). Branded? London: V\&A Publications.

10. https://www.indiatoday.in/elections/lok-sabha-2019/story/election-results-2019-bjp-nda-performancesouth-india-kerala-karnataka-tamil-nadu-andhra-pradesh-telangana-1533789-2019-05-24

11. https://en.wikipedia.org/wiki/2017_Punjab_Legislative_Assembly_election

12. https://en.wikipedia.org/wiki/2019_Indian_general_election

13. https://en.wikipedia.org/wiki/Results_of_the_2019_Indian_general_election 